University of Nebraska - Lincoln

DigitalCommons@University of Nebraska - Lincoln

2006

\title{
Introduction to the Special Issue on Emotion in Legal Judgment and Decision Making
}

Brian H. Bornstein

University of Nebraska-Lincoln, bbornstein2@unl.edu

Follow this and additional works at: https://digitalcommons.unl.edu/psychfacpub

Part of the Psychiatry and Psychology Commons

Bornstein, Brian H., "Introduction to the Special Issue on Emotion in Legal Judgment and Decision Making" (2006). Faculty Publications, Department of Psychology. 342.

https://digitalcommons.unl.edu/psychfacpub/342

This Article is brought to you for free and open access by the Psychology, Department of at DigitalCommons@University of Nebraska - Lincoln. It has been accepted for inclusion in Faculty Publications, Department of Psychology by an authorized administrator of DigitalCommons@University of Nebraska - Lincoln. 
Published in Law and Human Behavior 30 (2006), pp. 115-118. Copyright ( 2006 American Psychology-Law Society/Division 41 of the American Psychological Association; published by Springer Verlag. Used by permission. http:// www.springerlink.com/link.asp?id=104390

Published online May 12, 2006

\title{
Introduction to the Special Issue on Emotion in Legal Judgment and Decision Making
}

\author{
Brian H. Bornstein and Richard L. Wiener \\ University of Nebraska-Lincoln, Lincoln, Nebraska, USA \\ Corresponding author-B. H. Bornstein, email bbornstein2@unl.edu
}

In the last decade, researchers have shown burgeoning interest in issues at the intersection of emotion and law. Given the longstanding interest in emotion among social (and other) psychologists, most of this research has come from a psychological perspective, but it also includes work with a legal, sociological, philosophical, and neuroscience flavor. The issues are theoretical as well as practical, influencing both psychological theories of emotion and matters of legal practice and policy.

The law adopts a double standard in its treatment of emotion. In some areas, the law explicitly addresses emotion as a legitimate consideration, but in other areas, the law denies emotion any role in legal decision making. For example, legal analysis requires decision makers to consider the emotional reactions of others when classifying certain offenses for purposes of criminal culpability (e.g., "hate crimes" and "crimes of passion"), awarding damages for emotional injuries (e.g., mental suffering and emotional distress), and allowing jurors' moral judgments to influence certain consequential decisions such as punitive damages, capital sentencing, and jury nullification. At the same time, the courts make what may be untenable presumptions when they require factfinders to ignore their affective states and evaluate evidence, such as gory crime scene photographs, dispassionately. Thus, the field of law and emotion is ripe for scholarly exploration.

This Special Issue samples some of the ways in which emotion is relevant to legal issues. The first two papers, by Terry Maroney and by Neil Feigenson and Jaihyun Park, locate the topic of emotion in legal judgment within a broader theoretical framework. Maroney asks the question of whether law and emotion, as a distinct research field, deserves the status of other "law-and" movements, such as law-and-psychology, law-and-economics, etc. Drawing on scholarship in a number of disciplines (e.g., psychology, law, sociology, and philosophy), she supports the academic status of law and emotion by presenting a descriptive taxonomy of this new field. In addition to organizing extant research on the topic, this taxonomy identifies gaps in the existing literature and suggests areas for future research. 
The paper by Feigenson and Park takes a somewhat narrower focus. It reviews research on the role of emotion in a specific type of legal judgment, namely, attributions of responsibility and blame. These sorts of attributions, which occur in a variety of social situations, are especially relevant to legal decision making in the negligence context (Feigenson, 2000). Drawing on the extensive research on affect and social judgment, Feigenson and Park discuss the various ways in which emotions and moods can influence factfinders' attributions of responsibility, and they propose a model that distinguishes among different types of affective influences. Their model effectively integrates and organizes prior research on emotion and attribution in the jury context, and it has clear implications for conducting future research in the area. Importantly, they also consider legal decision makers' ability to correct for affective influences in their reasoning - that might or might not be desirable from a normative perspective. An awareness of potential bias is often viewed as a necessary first step toward its elimination, but as a wealth of research has demonstrated, it is often not sufficient (Fischhoff, 1982).

The next four papers are experimental studies that address the role of emotion in legal factfinding. Horowitz, Kerr, Park, and Gockel ask whether informing jurors of their nullification power would focus the jury on emotional rather than evidentiary factors and thereby invite "chaos" into the courtroom. They find that emotionally biasing information (i.e., a sympathetic vs. an unsympathetic victim) has its greatest impact when nullification instructions are provided in a nullification-relevant case (i.e., euthanasia, as opposed to murder for profit). The results extend the authors' prior work on jury nullification (Niedermeier, Horowitz, \& Kerr, 1999) by showing that one way nullification instructions may operate is by legitimizing emotions as valid information for jurors to use in reaching a verdict. Moreover, they show that nullification instructions may be problematic in some types of cases but not others.

The study by Horowitz et al. explores the effect of emotionally biasing extra-legal information; Bright and Goodman-Delahunty, on the other hand, examine the effect of emotionally biasing evidence presented at trial. Although courts tend to assume that gruesome evidence will have a prejudicial effect on jurors' verdicts, research testing this assumption has yielded mixed results (Bornstein \& Nemeth, 1999). Bright and GoodmanDelahunty shed some light on these inconsistent findings by showing that gruesome photographic evidence exerts a stronger effect than gruesome verbal testimony, and that the influence of the gruesome photographs is mediated by mock jurors' anger response.

The next two papers examine how observers' expectations of victims' conduct influence the way in which legal actors perceive them. Victims' reactions to crime, especially their emotional responses, can influence a variety of legally relevant judgments. For example, if a victim appears untroubled by a set of injurious events, authorities might be less convinced that a crime has actually taken place, making police less likely to investigate and prosecutors less likely to file charges. Furthermore, victims' emotional reactions, both at the time of the crime and while testifying, can affect their credibility at trial. Rose, Nadler, and Clark explore these issues within the context of victim impact evidence during the sentencing phase of a criminal trial, by crossing a crime victim's emotional reaction (severe vs. mild) with the seriousness of the crime (e.g., armed robbery vs. pickpocketing). They find that there is not a simple effect of emotion in this context, but rather that people expect victims to match the intensity of their emotional response to the seriousness of the event (i.e., they adhere to a proportionality rule in evaluating victims' credibility). Interestingly, they report that although a victim's emotional response affects various measures of how mock jurors perceive the victim, it does not affect their recommended punishment for the defendant.

The following paper by Wessel, Drevland, Eilertsen, and Magnussen shows that these effects are not inevitable. Like Rose et al., they manipulate a crime victim's emotional response, here for an alleged acquaintance rape. Previous research (Kaufmann, Drevland, 
Wessel, Overskeid, \& Magnussen, 2003) had found that, similar to the findings of the Rose et al. study, rape victims who display a proportional and congruent emotional response (i.e., who are demonstrably upset) while talking about the event are more credible than victims who display incongruent emotion (i.e., who are positive and relaxed). However, in this study, a sample of Norwegian judges was not affected by the victim's emotional response. Thus, factfinders' training and experience may be capable of offsetting the unwanted effects of victims' emotional reactions. This finding begs the question of whether a victim's emotional reaction should influence legal decision making. Is a very upset victim more likely to be telling the truth than a stoic victim? Should punishment be greater when the crime has engendered more severe emotional consequences? With respect to the first question, a speaker's emotional demeanor can be a reliable cue to his or her veracity (Vrij, 2000); whereas with regard to the second question, the mere admissibility of victim impact evidence suggests that courts do view a crime's emotional impact as a legitimate consideration in sentencing (Greene, 1999).

The Special Issue concludes with a paper by Wiener, Bornstein, and Voss, which draws on research in social and cognitive psychology to show how theories of judgment and decision making that incorporate decision makers' affective responses apply to various legal contexts. It takes two widely used models of decision making, the rational actor and lens models, and illustrates their utility for understanding legal judgments by using them to interpret existing research findings in the areas of juror decision making, people's obedience to the law (e.g., paying taxes), and eyewitness memory.

Although the present set of papers makes a valuable contribution to the study of emotion in legal judgment, the work represented here also makes apparent that psycholegal researchers have merely scratched the surface of this vibrant field. As the reviews by Maroney, Feigenson, and Park, and Wiener et al. make all too clear, this Special Issue represents only a small fraction of the research possibilities at the intersection of law and emotion. For example, emotion is of paramount importance in addressing issues such as the effects of stress on eyewitness memory (Deffenbacher, Bornstein, Penrod, \& McGorty, 2004), the causes and consequences of hate crimes (Boeckmann \& Turpin-Petrosino, 2002), a number of clinical-forensic issues, such as emotional disorders in criminal populations (e.g., psychopathy; see Hare, 1996), and the assessment.of emotional injuries in civil litigation (Goodman-Delahunty \& Foote, 1995). And this is by no means an exhaustive list. As Editors of this Special Issue, we find it encouraging that so many scholars, from diverse fields, are beginning to turn their attention to the role of emotion in legal decision making; and at the same time, we are excited by the many challenging questions that researchers have not yet begun to address.

\section{References}

Boeckmann, R. J., \& Turpin-Petrosino, C. (2002). Understanding the harm of hate crime. Journal of Social Issues, 58, 207-225.

Bornstein, B. H., \& Nemeth, R. J. (1999). Jurors' perception of violence: a framework for inquiry. Aggression and Violent Behavior, 4, 77-92.

Deffenbacher, K. A., Bornstein, B. H., Penrod, S. D., \& McGorty, E. K. (2004). A meta-analytic review of the effects of high stress on eyewitness memory. Law and Human Behavior, 28, 687-706.

Feigenson, N. (2000). Legal blame: How jurors think and talk about accidents. Washington, DC: American Psychological Association.

Fischhoff, B. (1982). Debiasing. In D. Kahneman, P. Slovic, \& A. Tversky (Eds.), Judgment under uncertainty: heuristics and baises (pp. 422-444). Cambridge: Cambridge University Press.

Goodman-Delahunty, J., \& Foote, W. E. (1995). Compensation for pain, suffering, and other psychological injuries. Behavioral Sciences \& the Law, 13, 183-206. 
Greene, E. (1999). The many guises of victim impact evidence and effects on jurors' judgments. Psychology, Crime and Law, 5, 331-348.

Hare, R. D. (1996). Psychopathy: a clinical construct whose time has come. Criminal Justice and Behavior, 23, 25-54.

Kaufmann, G., Drevland, G. C. B., Wessel, E., Overskeid, G., \& Magnussen, S. (2003). The importance of being earnest: displayed emotions and witness credibility. Applied Cognitive Psychology, $17,21-34$.

Niedermeier, K., Horowitz, I.A., \& Kerr, N. L. (1999). Informing jurors of their nullification power: a route to a just verdict or judicial chaos? Law and Human Behavior, 23, 331-351.

Vrij, A. (2000). Detecting lies and deceit: psychology of lying and the implication for professional practice. Chichester, Great Britain: Wiley. 